\title{
Produktivitas Induk Babi yang Diberi Pakan Tambahan Tepung Feses Sapi dan Probiotik
}

\author{
(Productivity of Sow Fed Additional Feed of Cow Feces Flour and Probiotics)
}

Dinata AANBS, Gunawan A

Balai Pengkajian Teknologi Pertanian Bali, Jl. By Pas Ngurah Rai Pesanggaran, Denpasar, Bali badunglahne@yahoo.co.id

\begin{abstract}
A study was conducted to determine the productivity of sows that fed by cow feces flour and probiotics. This research conducted in Paras Paros Group Farmers, Padangsambian Kaja Village, West Denpasar District, Denpasar City. Total of 24 sows of 70 days gestation periods were arranged into four groups with six head per treatment. The first treatment was fed as ordinary farmers way (B1), the second treatment with B1 and additional probiotic Bio-B $2 \mathrm{cc} / \mathrm{l}(\mathrm{B} 2)$, the third treatment sows fed with an additional form of cow feces flour $25 \%$ of the total ration (B3) and the fourth treatment was B3 treatments + probiotic Bio-B $2 \mathrm{cc} / 1$ of drinking water (B4). Parameters observed were: (1) The length of gestation; (2) Litter size; (3) Child mortality; (4) Birth weight; and (5) Weaning weight. From this research data showed the average length of gestation 111-114 days, 11 to 11.8 heads litter size and mortality from 1.8 to 2 heads. The result showed that birth weight and weaning weight of B4 was the highest which was respectively 1.9 and 9.85 $\mathrm{kg} / \mathrm{h}$ ead was significantly higher $(\mathrm{P}<0.05)$ compared to treatments $\mathrm{B} 1$. Treatment $\mathrm{B} 2$ significantly higher on birth weight, whereas was not significantly different between B3 and B1. From this study can be concluded that giving of cow feces flour as much as $25 \%$ of the ration with the addition of probiotics increase the production of sows.
\end{abstract}

Key Words: Sow, Feces Flour, Probiotics

\begin{abstract}
ABSTRAK
Suatu penelitian dilakukan untuk mengetahui produktivitas induk babi yang diberi pakan tambahan tepung feses sapi dan probiotik. Penelitian dilaksanakan di Kelompok Ternak Paras Paros, Desa Padangsambian Kaja, Kecamatan Denpasar Barat, Kota Denpasar. Sebanyak 24 ekor induk babi Landrace dalam kondisi bunting 70 hari dibagi kedalam empat kelompok perlakuan, dengan masing-masing perlakuan berjumlah enam ekor. Keempat perlakuan tersebut adalah induk babi diberi pakan sesuai dengan cara petani (B1), induk babi diberi tambahan probiotik Bio-B 2 $\mathrm{cc} / \mathrm{l}$ air minum (B2), induk babi diberi pakan tambahan berupa tepung feses sapi $25 \%$ dari total ransum (B3) dan induk babi diberi pakan sama dengan perlakuan B3 + probiotik Bio-B $2 \mathrm{cc} / \mathrm{l}$ air minum (B4). Parameter yang diamati adalah (1) Lama kebuntingan; (2) Litter size, (3) Angka kematian anak; (4) Bobot lahir; dan (5) Bobot sapih. Hasil penelitian ini mendapatkan data ratarata lama kebuntingan 111-114 hari, litter size 11-11,8 ekor dan angka kematian 1,8-2 ekor. Induk babi perlakuan B4 memiliki bobot lahir dan bobot sapih anak paling tinggi yakni masing-masing 1,9 dan $9,85 \mathrm{~kg} /$ ekor nyata lebih tinggi $(\mathrm{P}<0,05)$ dibandingkan dengan perlakuan $\mathrm{B} 1$. Perlakuan $\mathrm{B} 2$ hanya berpengaruh nyata pada bobot lahir, sedangkan perlakuan B3 tidak berbeda nyata dibandingkan perlakuan B1. Dapat disimpulkan bahwa pemberian tepung feses sapi sebanyak $25 \%$ dari ransum dengan penambahan probiotik mampu meningkatkan produktivitas induk babi.
\end{abstract}

Kata Kunci: Induk Babi, Feses Sapi, Probiotik 


\section{PENDAHULUAN}

Ternak babi memiliki beberapa keunggulan dibandingkan dengan ternak lainnya yakni laju pertumbuhan yang cepat dengan persentase karkas sebesar 65-70\% (Budaarsa 2012), litter size tinggi, omnivora (pemakan segala jenis makanan) dan resisten terhadap beberapa penyakit. Ternak babi sangat peridi (prolific), satu kali beranak bisa 6-12 ekor (Sinaga et al. 2010). Walaupun demikian produktivitas ternak babi masih belum optimal. Hal ini tergambar dari masih tingginya kematian embrio selama periode kebuntingan dan kematian anak prasapih serta semakin besar persentase anak yang lahir di bawah bobot normal (Geisert \& Schmitt 2002).

Bobot lahir anak babi dipengaruhi oleh beberapa faktor seperti genetik, makanan, jumlah anak dalam kandungan, jenis kelamin anak serta sudah berapa kali induk babi tersebut melahirkan (Sihombing 2006). Pertumbuhan dan perkembangan embrio yang baik selama kebuntingan dapat meningkatkan bobot lahir, bobot prasapih dan bobot akhir walaupun dengan jumlah anak sekelahiran yang lebih besar (Vallet et al. 2004). Induk babi yang baik mampu beranak lima kali dalam kurun waktu dua tahun dengan memperhatikan waktu atau periode menyusui, periode sapihan dan masa kering induk serta waktu pelaksanaan perkawinan (Montong 2011).

Tingkat konsumsi daging babi di Bali sangat tinggi yakni sebanyak 23 $\mathrm{kg} / \mathrm{kapita} / \mathrm{tahun}$. Untuk memenuhi kebutuhan babi guling saja, Bali memerlukan sekitar 91.880 ekor babi muda setiap tahunnya (Budaarsa 2012). Di sisi lain, populasi ternak babi di Bali terus mengalami penurunan. Untuk tahun 2015 populasi ternak babi sebanyak 794.936 ekor mengalami penurunan sebesar 10,74\% dari tahun 2012 yakni sebesar 890.598 ekor (Ditjen PKH 2016). Penurunan populasi disebabkan rendahnya harga daging babi yang tidak sebanding dengan biaya yang dikeluarkan terutama biaya untuk pakan, sehingga kebanyakan peternak mengalami kerugian dan mengurangi volume usahanya.

Menurut Sihombing (2006), biaya produksi terbesar dalam usaha ternak babi ialah biaya pakan yang mencapai $65-80 \%$ dari total biaya produksi. Hal ini disiasati oleh beberapa peternak dengan memberikan pakan berupa limbah. Salah satu limbah yang jumlahnya berlimpah adalah kotoran sapi. Pada umumnya pemanfaatan limbah sapi masih terbatas untuk sumber pupuk organik. Padahal dari sisi kandungan nutrisi feses sapi segar mengandung protein kasar sebesar 7,22\% dan serat kasar 44,11\%. Melalui proses fermentasi dengan inokulan yang mengandung mikroba dari saluran pencernaan rayap selama lima hari dapat meningkatkan kandungan protein kasar menjadi 14,80\% (Guntoro et al. 2013). Penggunaan kotoran sapi terfermentasi disajikan dalam bentuk tepung sebanyak $15 \%$ dari ransum ayam buras petelur dilaporkan tidak menyebabkan penurunan jumlah dan berat telur (Guntoro et al. 2015). Pemberian tepung kotoran sapi bisa ditingkatkan sampai $20 \%$ dari total ransum dengan penambahan probiotik menyebabkan turunnya angka feed convertion ratio secara nyata (Guntoro et al. 2016).

Upaya lain untuk meningkatkan produktivitas ternak babi adalah melalui peningkatan kecernaan dengan pemberian probiotik. Probiotik merupakan mikroorganisme hidup yang diaplikasikan secara oral dengan tujuan untuk meningkatkan kesehatan dan penyerapan nutrisi ternak dengan cara memanipulasi mikroba yang berada dalam tubuh ternak (Pribadi et al. 2015). Penggunaan probiotik merupakan salah satu upaya peningkatan kecernaan bahan pakan sehingga lebih banyak zat nutrisi yang dapat diserap (Astuti et al. 2015). Jaya et al. (2015) mendapatkan bahwa pemberian probiotik sebanyak 0,25\% dalam ransum dapat meningkatkan pertambahan bobot badan babi Landrace persilangan. Dilaporkan pula oleh Suryana et al. (2015) bahwa penambahan probiotik sebanyak 0,25\% dalam ransum dapat meningkatkan bobot karkas babi Landrace persilangan. 
Penelitian pemberian tepung feses sapi sudah dilakukan pada ternak unggas dan memberikan hasil yang memuaskan. Penggunaan tepung feses sapi ini juga perlu dicoba pada induk babi sebagai pengganti dedak padi dalam ransum. Oleh karena itu, tujuan penelitian ini adalah untuk mengetahui produktivitas induk babi yang diberi pakan tambahan tepung feses sapi dan probiotik. Hasil penelitian ini diharapkan akan bisa dijadikan acuan dalam meningkatkan produktivitas induk babi

\section{MATERI DAN METODE}

Penelitian dilaksanakan di Kelompok Ternak Paras Paros Desa Padangsambian Kaja, Kecamatan Denpasar Barat, Kota Denpasar. Sebanyak 24 ekor induk babi landrace dalam kondisi umur kebuntingan 70 hari dibagi kedalam empat kelompok perlakuan, dengan masing-masing perlakuan berjumlah enam ekor. Keempat perlakuan tersebut adalah induk babi diberi pakan sesuai dengan cara petani (B1), induk babi diberi tambahan probiotik Bio-B $2 \mathrm{cc} / \mathrm{l}$ air minum (B2), induk babi diberi pakan tambahan berupa tepung kotoran sapi 25\% dari total ransum (B3) dan induk babi diberi perlakuan sama dengan B3 + probiotik Bio-B $2 \mathrm{cc} / \mathrm{l}$ air minum (B4). Bio-B merupakan probiotik produk komersial dalam bentuk cair yang mengandung mikroba menguntungkan yang diisolasi dari saluran pencernaan babi. Adapun komposisi pakan yang diberikan disajikan pada Tabel 1 .

Tabel 1. Komposisi dan kandungan nutrisi ransum induk babi

\begin{tabular}{lcccc}
\hline \hline \multirow{2}{*}{ Ransum (\%) } & \multicolumn{4}{c}{ Perlakuan } \\
\cline { 2 - 5 } Komposisi & B1 & B2 & B3 & B4 \\
Konsentrat CP 551 & 50 & 50 & 50 & 50 \\
Dedak padi & 50 & 50 & 25 & 25 \\
Tepung feses sapi & 0 & 0 & 25 & 25 \\
Total & 100 & 100 & 100 & 100 \\
Probiotik Bio-B ${ }^{1)}$ & - & 2 cc & - & 2 cc \\
Kandungan nutrisi ${ }^{2)}$ & & & & \\
Bahan kering (BK) & 86,41 & 86,41 & 86,29 & 86,29 \\
Abu & 12,59 & 12,59 & 13,64 & 13,64 \\
Bahan organik (BO) & 87,41 & 87,41 & 86,36 & 86,36 \\
Protein kasar (PK) & 13,43 & 13,43 & 13,72 & 13,72 \\
Lemak kasar (LK) & 4,75 & 4,75 & 3,61 & 3,61 \\
Serat kasar (SK) & 20,09 & 20,09 & 19,74 & 19,74 \\
Ca & 0,89 & 0,89 & 0,96 & 0,96 \\
P & 0,80 & 0,80 & 0,70 & 0,70 \\
\hline
\end{tabular}

${ }^{1)}$ Probiotik yang ditambahkan ke dalam ransum sebagai aditif; ${ }^{2)}$ Nutrisi dihitung berdasarkan hasil analisa laboratorium Lolitsapi

Tepung feses sapi yang digunakan dibuat dari feses sapi yang telah diolah melalui proses fermentasi. Proses fermentasi menggunakan inokulan khusus yang mengandung mikroba selulolitik yang diisolasi dari saluran pencernaan rayap. Sebelum digunakan untuk fermentasi inokulan diperbanyak dalam media cair. Air yang digunakan adalah air bersih yang sebelumnya dimasak dahulu sampai mendidih kemudian didinginkan. Untuk 10 liter 
air ditambahkan gula merah dan inokulan masing masing sebanyak 1\%. Campuran tersebut diaduk sampai merata kemudian didiamkan selama 30 menit untuk memberikan kesempatan mikroba berkembangbiak. Tutup selama 30 menit baru kemudian disiramkan pada bahan secara merata. Fermentasi dilakukan secara anaerob selama lima hari di dalam kotak fermentasi. Limbah kemudian dijemur hingga kering selanjutnya digiling sehingga berbentuk tepung. Dari hasil analisis proksimat tepung feses sapi memiliki kandungan bahan kering (BK) 85,34\%; abu 21,37\%; bahan organik (BO) 78,63\%; protein kasar (PK) 9,52\%; lemak kasar 0,93\%; serat kasar (SK) 32,77\%; kalsium (Ca) 1,16\%; dan fosfor (P) $0,29 \%$. Adapun skema pembuatan tepung feses sapi dapat dilihat pada Gambar 1 .

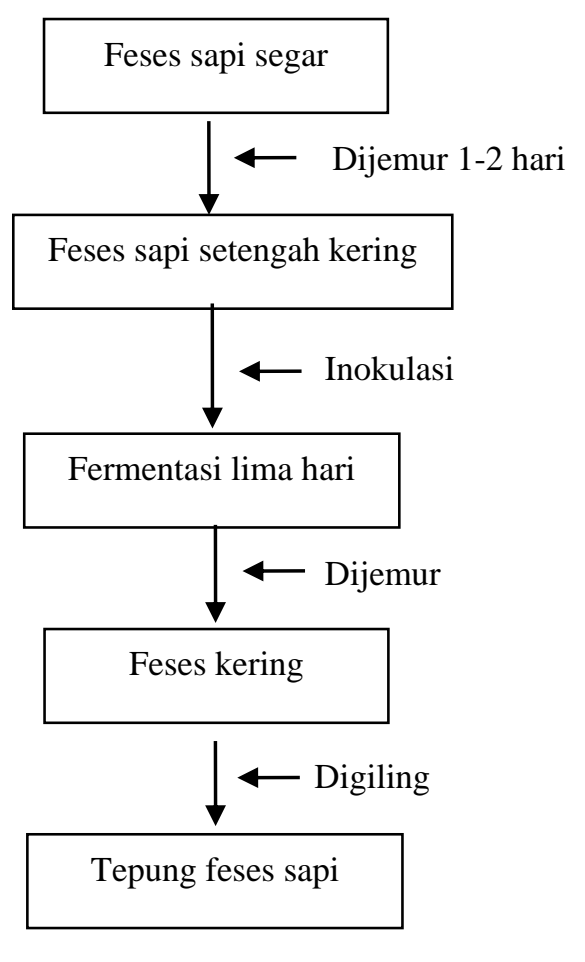

Gambar 1. Skema pembuatan tepung feses sapi

Pakan perlakuan diberikan pada induk babi dari umur kebuntingan 70 hari sampai dengan melahirkan. Ransum babi yang diberikan terdiri atas pakan komersial yakni konsentrat CP 551, dedak padi dan tepung feses sapi. Sebelum diberikan ransum dicampur menjadi satu sesuai dengan perlakuan. Ransum diberikan dua kali dalam sehari yakni 50\% pada pagi hari dan sisanya 50\% pada sore hari. Total jumlah ransum yang diberikan adalah sebanyak $5 \mathrm{~kg} / \mathrm{hari}$. Air minum diberikan pada waktu yang bersamaan dengan pemberian pakan secara ad libitum.

Parameter yang diamati dalam penelitian ini adalah: (1) Lama kebuntingan; (2) Litter size; (3) Angka kematian anak; (4) Bobot lahir; dan (5) Bobot sapih. Lama kebuntingan merupakan periode waktu yang diukur dari sejak dikawinkan sampai dengan melahirkan. Tanggal perkawinan dicatat yang digunakan sebagai dasar penentuan umur kebuntingan. Litter size merupakan jumlah anak yang dilahirkan dalam satu kelahiran. Kematian anak dihitung dari sejak melahirkan sampai anak babi disapih. Untuk mengetahui bobot lahir dilakukan penimbangan pada anak babi yang baru lahir. Pengukuran bobot sapih dilakukan dengan penimbangan anak babi setelah disapih yakni pada umur 30 hari. Data yang diperoleh dianalisis dengan analisis varians (sidik ragam) dengan tingkat kesalahan $5 \%$. Apabila diperoleh perbedaan diantara perlakuan dilanjutkan uji jarak berganda dari Duncan. 


\section{HASIL DAN PEMBAHASAN}

Lama kebuntingan adalah periode waktu dari mulai terjadinya fertilisasi sampai dengan kelahiran. Rata-rata lama kebuntingan babi pada penelitian ini adalah berkisar antara 111-114 hari (Tabel 2). Data ini tidak berbeda dengan data yang diperoleh pada penelitian sebelumnya, dimana lama kebuntingan babi adalah 114 hari (Asih 2003), 111120 hari (Ardana \& Putra 2008) dan 111-117 hari (Toelihere1993).

Tabel 2. Kinerja reproduksi induk babi

\begin{tabular}{lccc}
\hline \hline Perlakuan $^{1)}$ & Lama kebuntingan (hari) & Litter size (ekor) & Angka kematian (ekor) \\
\hline B1 & $112^{\mathrm{a}} \pm 1,67$ & $11,83^{\mathrm{a}} \pm 2,79$ & $1,67^{\mathrm{a}} \pm 0,52$ \\
B2 & $111^{\mathrm{a}} \pm 1,10$ & $11,50^{\mathrm{a}} \pm 1,05$ & $1,67^{\mathrm{a}} \pm 0,52$ \\
B3 & $114^{\mathrm{a}} \pm 2,28$ & $11,33^{\mathrm{a}} \pm 1,75$ & $2,00^{\mathrm{a}} \pm 0,63$ \\
B4 & $113^{\mathrm{a}} \pm 2,75$ & $11,00^{\mathrm{a}} \pm 2,96$ & $1,83^{\mathrm{a}} \pm 0,41$ \\
\hline
\end{tabular}

${ }^{1)}$ Nilai dengan huruf berbeda pada kolom yang sama menunjukkan perbedaan yang nyata; B1: Induk babi diberi pakan sesuai dengan cara petani; B2: Induk babi diberi tambahan probiotik Bio-B $2 \mathrm{cc} / \mathrm{l}$ air minum; B3: Induk babi diberi pakan tambahan berupa tepung kotoran sapi 25\% dari total ransum; B4: Induk babi diberi perlakuan sama dengan B3 + probiotik Bio-B $2 \mathrm{cc} / \mathrm{l}$ air minum

Rata-rata litter size babi seluruh perlakuan adalah sebesar 11,417 ekor/induk. Data ini telah sesuai dengan standar target kinerja reproduksi induk babi dan termasuk dalam katagori baik yakni di atas 11,3 ekor/induk (Close 2001). Litter size antar perlakuan secara statistik tidak berbeda nyata $(\mathrm{P}>0,05)$. Demikian juga pada angka kematian secara statistik menunjukkan tidak berbeda nyata $(\mathrm{P}>0,05)$. Kematian pada anak babi paling banyak terjadi pada umur 1-7 hari. Tidak ditemukan adanya kematian yang diakibatkan serangan penyakit pada anak babi seluruh perlakuan. Penyebab kematian biasanya akibat kedinginan dan tertindih oleh tubuh induknya. Anak babi umur 3-10 hari mengalami masa kritis, sangat sensitif dan tidak berdaya menghadapi lingkungan yang berat, anak babi mudah kedinginan, anak babi banyak mati tertindih dan mati lemas (Yudhie 2009). Hal ini mengindikasikan bahwa pemberian pakan berupa dedak kotoran ternak sapi sebanyak 25\% dalam total ransum pada perlakuan B3 dan B4 tidak berpengaruh negatif terhadap kesehatan induk maupun anak babi.

Kisaran bobot lahir anak babi adalah antara 1,51-1,90 kg/ekor (Tabel 3). Kisaran bobot lahir pada penelitian ini berbeda dengan yang didapatkan oleh Sihombing (2006) menyatakan bahwa bobot lahir anak babi bervariasi antara 1,09-1,77 kg. Rata-rata bobot lahir paling tinggi terdapat pada induk babi yang memperoleh perlakuan B4 yakni sebesar $1,9 \mathrm{~kg} / \mathrm{ekor}$ atau 25,83 dan $19,5 \%$ nyata lebih tinggi $(\mathrm{P}<0,05)$ dibandingkan dengan perlakuan B1 dan B3. Rata-rata bobot lahir ini berbanding lurus dengan rata-rata bobot lahir totalnya. Hal ini menunjukkan bahwa pemberian probiotik Bio-B berpengaruh pada meningkatnya bobot lahir dari anak babi.

Probiotik merupakan mikroorganisme hidup yang diaplikasikan secara oral dengan tujuan untuk meningkatkan kesehatan dan penyerapan nutrisi ternak dengan cara memanipulasi mikroba yang berada dalam tubuh ternak (Pribadi et al. 2015). Penambahan probiotik akan dapat meningkatkan populasi mikroba, meningkatkan fungsi dan kesehatan serta penyerapan zat makanan dalam saluran pencernaan (Kompiang 2009; Musa et al. 2009; Mountzouris et al. 2010). Sumadi et al. (2015) menyatakan suplementasi probiotik (starbio) dalam pakan babi telah nyata dapat menurunkan konsumsi pakan, meningkatkan pertambahan berat badan dan menurunkan feed convertion ratio (FCR). 
Tabel 3. Bobot lahir dan bobot sapih anak babi pada induk yang diberi pakan tambahan tepung feses sapi dan probiotik

\begin{tabular}{lcccc}
\hline \hline Perlakuan ${ }^{1)}$ & $\begin{array}{c}\text { Bobot lahir } \\
(\text { kg/ekor })\end{array}$ & $\begin{array}{c}\text { Bobot sapih } \\
(\text { kg/ekor })\end{array}$ & $\begin{array}{c}\text { Bobot lahir total } \\
(\mathrm{kg})\end{array}$ & $\begin{array}{c}\text { Bobot sapih total } \\
(\mathrm{kg})\end{array}$ \\
\hline B1 & $1,51^{\mathrm{a}} \pm 0,48$ & $7,73^{\mathrm{a}} \pm 0,78$ & $17,82^{\mathrm{a}} \pm 1,02$ & $77,3^{\mathrm{a}} \pm 4,64$ \\
B2 & $1,68^{\mathrm{ab}} \pm 0,18$ & $8,54^{\mathrm{ab}} \pm 1,07$ & $19,32^{\mathrm{b}} \pm 1,11$ & $82,84^{\mathrm{ab}} \pm 2,68$ \\
B3 & $1,59^{\mathrm{a}} \pm 0,18$ & $8,28^{\mathrm{ab}} \pm 0,82$ & $18,13^{\mathrm{a}} \pm 1,07$ & $77,83^{\mathrm{a}} \pm 4,85$ \\
B4 & $1,90^{\mathrm{b}} \pm 0,10$ & $9,85^{\mathrm{b}} \pm 1,66$ & $20,9^{\mathrm{b}} \pm 1,09$ & $89,64^{\mathrm{b}} \pm 2,94$ \\
\hline
\end{tabular}

${ }^{1)}$ Nilai dengan huruf berbeda pada kolom yang sama menunjukkan perbedaan yang nyata; B1: Induk babi diberi pakan sesuai dengan cara petani; B2: Induk babi diberi tambahan probiotik Bio-B $2 \mathrm{cc} / \mathrm{l}$ air minum; B3: Induk babi diberi pakan tambahan berupa tepung kotoran sapi $25 \%$ dari total ransum; B4: Induk babi diberi perlakuan sama dengan B3 + probiotik Bio-B $2 \mathrm{cc} / \mathrm{l}$ air minum

Penambahan tepung feses sapi meningkatkan kandungan nutrisi ransum, dengan kandungan PK lebih tinggi dan SK yang lebih rendah (Tabel 1). Namun, penambahannya dalam ransum tidak mampu meningkatkan bobot lahir maupun bobot sapih anak secara nyata. Hal ini disebabkan masih tingginya kandungan serat kasar pada ransum yang diberikan. Kebutuhan babi akan serat kasar adalah maksimum sebesar 6\% (NRC 1998). Wira (2014) menyatakan ternak babi yang memiliki lambung sederhana memiliki kemampuan yang sangat terbatas untuk mencerna serat kasar. Penambahan probiotik akan membantu meningkatkan proses-proses enzimatik di dalam saluran pencernaan babi sehingga kecernaan nutrisi pakan menjadi lebih tinggi (Sumadi et al. 2015). Lebih tingginya kandungan nutrien dan meningkatnya kecernaan menyebabkan nutrien yang terserap menjadi lebih tinggi. Hal ini akan berpengaruh pada jumlah nutrien yang diserap feotus dalam kandungan menjadi lebih tinggi sehingga menyebabkan bobot lahirnya menjadi lebih tinggi. Pendapat ini sejalan dengan pernyataan Lapian (2012) yang menyatakan bobot anak saat lahir ditentukan oleh pertumbuhan prenatal (selama dalam kandungan). Hal ini juga berpengaruh pada bobot sapih anak babi adalah yang tertinggi pada induk babi perlakuan B4 yakni sebesar 9,85 kg/ekor. Paling tingginya bobot sapih pada induk babi perlakuan B4 disebabkan oleh lebih tingginya jumlah nutrien yang diserap untuk menghasilkan air susu. Sihombing (2006) menyatakan produksi susu yang tinggi dapat meningkatkan bobot badan anak dan meningkatkan bobot sapih. Produksi susu yang tinggi menyebabkan kebutuhan nutrien anak akan terpenuhi sehingga menyebabkan pertambahan bobot badannya menjadi lebih tinggi.

\section{KESIMPULAN}

Tepung feses sapi bisa diberikan sebanyak 25\% dalam ransum induk babi dengan penambahan probiotik. Penambahan probiotik Bio-B dapat meningkatkan pemanfaatan ransum dalam tubuh induk babi sehingga menyebabkan bobot lahir dan bobot sapih pada perlakuan B4 menjadi paling tinggi

\section{DAFTAR PUSTAKA}

Ardana IB, Putra DKH. 2008. Ternak babi. Manajemen reproduksi, produksi dan penyakit. Denpasar (Indonesia): Udayana University Press. 
Asih RS. 2003. Produksi ternak babi. Laporan teaching grant. Lombok. (Indonesia): Departemen Pendidikan Nasional, Universitas Mataram.

Astuti FK, Busono W, Sjofjan O. 2015. Pengaruh penambahan probiotik cair dalam pakan terhadap penampilan produksi pada ayam pedaging. J-PAL. 6:99-104.

Budaarsa K. 2012. Babi guling Bali. Dari beternak, kuliner, hingga sesaji. Denpasar (Indonesia): Buku Arti-Denpasar.

Close WH. 2001. Feeding and management strategies to improve sow productivity. Asian Pork Magazine.

Ditjen PKH. 2016. Statistik peternakan dan kesehatan hewan 2016. Jakarta (Indonesia): Direktorat Jenderal Peternakan dan Kesehatan Hewan, Kementerian Pertanian.

Geisert DR, Schmitt RAM. 2002. Early embryonic survival in the pig: Can it be improved. J Anim Sci. 80:54-85.

Guntoro S, Raiyasa IM, Dinata AANBS, Sudarma IW. 2013. Pemanfaatan feses sapi untuk pakan itik Bali jantan. JPPTP. 16:77-84.

Guntoro S, Dinata AANBS, Sudarma IW. 2015. Pemanfaatan feses sapi untuk bahan ransum ayam buras. JPPTP. 18:217-224.

Guntoro S, Dinata AANBS, Sudarma IW. 2016. Kombinasi penggunaan tepung feses sapi dalam ransum dan pemberian probiotik pada ayam buras petelur. J Biologi. 20:47-52.

Jaya IGAD, Ariana INT, Oka AA. 2015. Pengaruh penambahan starbio dalam ransum terhadap dimensi tubuh luar dan berat badan babi landrace persilangan. J Trop Anim Sci. 3:418-429.

Kompiang IP. 2009. Pemanfaatan mikroorganisme sebagai probiotik untuk meningkatkan produksi ternak unggas di Indonesia. J Pengembangan Inovasi Pertanian. 2:177-191.

Lapian MTR. 2012. Peformans bakalan yang dilahirkan oleh induk babi yang diovulasi ganda dengan PMSG dan hCG sebelum pengawinan [Disertasi]. [Bogor (Indonesia)]. Institut Pertanian Bogor.

Montong PRRI. 2011. Pedoman praktis dan teori manajemen peternakan babi. Jakarta (Indonesia) Cahaya Pineleng.

Mountzouris K, Tsitrsikos CP, Palamidi I, Arvaniti A, Mohnl M, Schatzmayr G, Fegeros K. 2010. Effects of probiotik inclusion levels in broiler nutrion on growth performance, nutrient digestibility, plasma immunoglobulins, and cecal micrroflora compostion. Poult Sci. 89:58-67.

Musa HH, Wu SL, Zhu CH, Seri HI, Zhu GQ. 2009. The potential benefits of probiotics in animal production and health. J Anim Vet Adv. 8:313-321.

NRC. 1998. Nutrient requirements of swine. 8th Ed. Washingtong DC (US): National Academy of Sciences,

Pribadi A, Kurtini T, Sumardi. 2015. Pengaruh pemberian probiotik dari mikroba lokal terhadap kualitas indek albumen, indek yolk dan warna yolk pada umur telur 10 hari. J Ilmiah Peternakan Terpadu. 3:180-184.

Sihombing DTH. 2006. Ilmu peternakan babi. Cetakan Kedua. Yogyakarta (Indonesia): Gajah Mada University Press.

Sinaga S, Silalahi M, Tarigan D. 2010. Pengaruh pemberian tepung bangung-bangun (Coleus amboinicus L) ke dalam ransum babi induk menyusui terhadap bobot sapih anak. Dalam: Prasetyo LH, Natalia L, Iskandar S, Puastuti P, Herawati T, Nurhayati, Anggraeni A, Damayanti R, Dharmayanti NLPI, Estuningsih SE, penyunting. Teknologi Peternakan dan Veteriner Ramah Lingkungan dalam Mendukung Program Swasembada Daging dan Peningkatan Ketahanan Pangan. Prosiding Seminar Nasional Teknologi Peternakan dan Veteriner. Bogor, 3-4 Agustus 2010. Bogor (Indonesia): Puslitbangnak. 
Sumadi IK, Wijaya IMG, Puger AW. 2015. Pengaruh suplementasi starbio dalam pakan dengan 40\% dedak padi terhadap penampilan babi Landrace. Majalah Ilmiah Peternakan. 18:30-34.

Suryana IMP, Ariana INT, Suryani NLP. 2015. Pengaruh pemberian probiotik kering starbio dalam ransum terhadap karakteristik karkas babi Landrace persilangan. J Trop Anim Sci. 3:468-481.

Toelihere MR. 1993. Inseminasi buatan pada ternak. Bandung (Indonesia): Percetakan Angkasa.

Vallet JL, Leimaster KA, Christenson RK. 2004. Efect of progesterone, mifepristone and esterogen treatment during early pregnancy on conceptus development and uterine capasity in swine. Biol Rep. 70:92-98.

Wira IWS. 2014. Recahan komersial karkas babi landrace persilangan yang diberi level sekam padi pada ransum mengandung limbah hotel [Skripsi]. [Denpasar (Indonesia)]: Universitas Udayana Denpasar.

Yudhie. 2009. Manajemen ternak babi [internet]. [disitasi 3 Juli 2017]. Tersedia dari: http://yudhiestar.blogspot.com/2009/12/manajemen-ternak-babi.html

\section{DISKUSI}

\section{Pertanyaan}

1. Mengapa dengan penambahan tepung feses sapi kandungan protein kasar meningkat dan serat kasar pada ransum menurun?

2. Bisakah tepung feses sapi ini digunakan dalam ransum ayam? Berapa persen pemberiannya?

\section{Jawaban}

1. Hal ini disebabkan kandungan protein kasar tepung feses sapi lebih tinggi dibandingkan dengan rata-rata kandungan protein kasar dedak padi yang digunakan dalam ransum yakni hanya sebesar 8,36\%. Kandungan serat kasar pada tepung feses sapi lebih rendah (32,77\%) dibandingkan dengan dedak padi (34,19\%) sehingga berpengaruh pada lebih rendahnya kandungan serat kasar pada ransum B3 dan B4.

2. Tepung feses sapi dapat diberikan pada ternak unggas termasuk ayam dengan porsi 15 $20 \%$ dari total ransum. Hasil penelitian sebelumnya menyatakan bahwa pemberian tepung feses sapi pada ayam buras petelur tidak menyebabkan penurunan berat telur secara nyata, tetapi secara ekonomis dirasakan oleh petani lebih menguntungkan. Pemanfaatan tepung feses sapi ini mampu menekan konsumsi pakan sehingga feed convertion ratio yang diperoleh semakin rendah. 